\title{
PERAN PENDIDIK DALAM MENGEMBANGKAN KREATIVITAS SENI ANAK USIA DINI DI KELOMPOK BERMAIN KORONKA BAWEN KABUPATEN SEMARANG
}

\author{
${ }^{1}$ Wahyu Trisnawati, ${ }^{2}$ Tri Joko Raharjo, ${ }^{3}$ Bagus Kisworo \\ 1,2,3 Jurusan Pendidikan Luar Sekolah, Fakultas Ilmu Pendidikan \\ Universitas Negeri Semarang \\ wahyutrisna.95@gmail.com
}

\begin{abstract}
ABSTRAK
Mengembangkan kreativitas di kelas merupakan faktor utama yang penting. Pendidik yang mengerti kreativitas dapat membantu peserta didik dalam mengembangkan kreativitas. Pendidik yang melatih serta mengajarkan kreativitas haruslah pendidik yang mempunyai jiwa kreatif. Rumusan masalah yang dikaji adalah bagaimana peran pendidik dalam mengembangkan kreativitas seni anak usia dini di Kelompok Bermain Koronka, bagaimana faktor pendukung pengembangan kreativitas seni anak usia dini di Kelompok Bermain Koronka, serta bagaimana faktor penghambat pengembangan kreativitas seni anak usia dini di Kelompok Bermain Koronka. pengumpulan data dilakukan dengan cara observasi, wawancara dan dokumentasi. Keabsahan data diperoleh melalui triangulasi sumber dan metode. Analisis data dimulai dari pengumpulan data melalui reduksi data, penyajian data, dan penarikan kesimpulan. Hasil yang diperoleh dalam penelitian ini adalah peran pendidik meliputi mendidik, mengajar, membimbing, mengarahkan, melatih, menilai, dan mengevaluasi peserta didiknya mengenai kreativitas seni. Pendidik yang kreatif sangat berpengaruh terhadap peserta didiknya. Selain itu, faktor yang mendukung kreativitas seni berasal dari dukungan orang tua serta sarana dan prasarana yang memadai. Sedangkan faktor yang menghambat kreativitas seni terletak pada pendidik atau orang tua yang mematahkan ide yang dikemukakan anak, persaingan antar anak, pembatasan terhadap rasa ingin tahu anak, pendidik yang banyak melarang anak, serta pola asuh orang tua yang terlalu mengawasi anak.
\end{abstract}

Kata Kunci: Peran Pendidik, Kreativitas Seni, Anak Usia Dini

\begin{abstract}
Developing creativity in the classroom is a major factor that matters. Educators who understand creativity can help learners in developing creativity. Educators who train and teach creativity must be educators who have a creative soul. The outline of the issue examined was how the role of educators in developing early childhood art creativity in Group Play Koronka, how to factor endowments development early childhood art creativity in Group Play Koronka, as well as how the factors restricting the development of creativity in early childhood Arts Groups Play Koronka. data collection is carried out by means of observation, interview and documentation. The validity of the data obtained through triangulation of sources and methods. Data analysis starts from data collection through the reduction of the data, the presentation of data, and the withdrawal of the conclusion. The results obtained in this research is the role of educators include educating, teaching, guiding, directing, train, assess, and evaluate his protégé participant about the creativity of art. Educators who creatively very influential towards the participants of his protégé. In addition, the factors that support the creativity of art comes from the support of parents as well as adequate infrastructure and facilities. While the factors that inhibit the creativity of art located on educators or parents who break the idea put forth child, competition between the child, the limitation on the child's curiosity, many educators forbid children, as well as parenting parents too keep an eye on the child.
\end{abstract}

Keywords: Educator Rule, Artistic Creativity, Early Childhood 


\section{PENDAHULUAN}

Pendidik adalah pihak utama yang langsung berhubungan dengan anak dalam upaya proses pembelajaran. Di Indonesia pembelajaran pra sekolah lebih bersifat akademik, sedikit pedidik yang memberikan kesempatan kepada peserta didik untuk bereksplorasi, mengekspresikan perasaannya, dan melakukan sendiri apa yang mereka minati, sampai menemukan pemecahan masalah sendiri. Peran pendidik dalam Pendidikan Anak Usia Dini (PAUD) meliputi peran sebagai perencana pembelajaran, perancang pembelajaran, pelaksana pembelajaran serta evaluator pembelajaran. Namun, saat ini banyak pendidik PAUD yang belum melaksanakan peran tersebut dengan baik karena berbagai persoalan. Banyak pendidik PAUD di Indonesia yang belum memenuhi kualifikasi S1 PG-PAUD sehingga mereka tidak terlalu mengerti tentang pembelajaran PAUD.

Pendidikan Anak Usia Dini (PAUD) merupakan suatu upaya pembinaan anak sejak lahir sampai usia enam tahun, yang dilakukan dengan memberi rangsangan pendidikan untuk membantu tumbuh kembangnya secara jasmani dan rohani mereka agar memiliki kesiapan memasuki pendidikan dasar (Mulyasa, 2012). Pada implementasinya, PAUD berfungsi membina, menumbuh kembangkan seluruh potensi anak secara optimal, agar terbentuk perilaku dan kemampuan dasar yang selaras, serasi, dan seimbang dengan tahap perkembangannya sehingga memiliki kesiapan untuk memasuki pendidikan selanjutnya dalam mewujudkan tujuan pendidikan nasional. PAUD dapat dijadikan sebagai cermin untuk melihat bagaimana keberhasilan anak di masa mendatang.

Undang-Undang Sisdiknas telah menegaskan bahwa Pendidikan Anak Usia Dini adalah suatu upaya pembinaan yang ditujukan kepada anak sejak lahir sampai usia enam tahun yang dilakukan melalui pemberian rangsangan pendidikan untuk membantu pertumbuhan dan perkembangan jasmani serta rohani agar anak memiliki kesiapan dalam memasuki pendidikan lebih lanjut.

Namun untuk mengembangkan kreativitas seni pada anak usia dini tidak hanya sekedar diberikan materi saja, akan tetapi diperlukan peran seorang pendidik yang sesuai dengan kriteria pendidik PAUD. Ketika pendidik tidak sesuai dengan kriteria maka akan berpengaruh terhadap semangat belajar anak usia dini. Pada umumnya permasalahan tenaga pendidik PAUD diakibatkan oleh beberapa faktor, diantaranya karena sebagian besar pendidik PAUD belum memenuhi kulifikasi S1 PG-PAUD, tingkat ekonomi pendidik PAUD rata-rata masih rendah, minimnya gaji pendidik PAUD sehingga mereka tidak mampu melanjutkan studinya di PGPAUD, lemahnya semagat belajar pendidik, tidak adanya perpustakaan khusus PAUD, dan sebagian besar pendidik PAUD adalah perempuan yang mempunyai kewajiban di rumah tangganya sebagai ibu dari anak-anaknya sehingga pekerjaan sebagai pendidik PAUD tidak maksimal, dan menjadi pendidik PAUD merupakan alternatif pekerjaan terakhir setelah pekerjaan lainnya tidak didapatkan.

Salah satu lembaga PAUD yang berdiri di Kabupaten Semarang adalah Children Early Education Center Koronka. Lembaga ini berlokasi di Jalan Diamond 442-443, Ambarawa Asri, Bawen. Koronka berasal dari bahasa Polandia yang artinya untaian manik-manik yang indah atau mahkota kecil yang indah. Siswa-siswi Koronka diandalkan sebagai manik-manik. Jika 
kita merangkai dengan benar akan menjadi mahkota kecil yang indah, kelak akan menjadi manusia yang takwa yang berguna bagi nusa dan bangsa. Jenis program yang terdapat dalam PAUD Koronka mencakup Kelompok Bermain (Play Group), TPA, dan Taman Kanak-kanak (TK). Program Kelompok Bermain (Play Group) mencakup 3 layanan, yaitu layanan Toodler Class, layanan Pra Play Group, dan layanan Play Group. Pendidik di PAUD Koronka berjumlah 5 orang dan sudah memenuhi kualifikasi S1 PG-PAUD, selain itu mereka juga mempunyai keahlian seni yang dapat mendukung proses pembelajaran. Pembelajaran di PAUD Koronka untuk Kelompok Bermain diarahkan pada pengembangan seni dengan pembelajaran berbasis sentra. Oleh karena itu, layanan pendidikan di Kelompok Bermain Koronka berperan dalam mengembangkan kreativitas seni pada anak (Sumber : PAUD Koronka; Rabu, 4 Januari 2017, Pukul 09:18).

\section{KAJIAN TEORI}

Saat ini banyak pendidik yang mengajar di lembaga PAUD bukan berpendidikan guru apa lagi pendidikan guru PAUD. Ada yang berpendidikan sarjana tapi bukan perpendidikan guru, seperti sarjana hukum, sarjana teknik, sarjana ekonomi. Ada juga yang hanya tamatan SMA/SMK yang sama sekali tidak memahami PAUD. Walaupun akhirnya untuk mengatasi kondisi itu, Kemendiknas mengeluarkan Permendiknas No. 16 tahun 2007 tentang kualifikasi kompetensi pendidik PAUD, disusul Permendiknas No. 58 tahun 2009 berisi kompetensi guru pendamping dan pengasuh (Masnipal, 2013).

Kebijakan pemerintah dalam peningkatan kualitas pendidik sudah banyak dilakukan, diantaranya dengan pelatihan dan workshop baik yang diselenggarakan ditingkat regional maupun nasional yang diselenggarakan oleh Dinas Pendidikan serta perguruan tinggi yang mempunyai program studi Pendidikan Guru PAUD. Walaupun masih dirasa kurang memadai dibandingkan dengan jumlah Guru PAUD yang ada.

Peran seorang pendidik PAUD sudah menjadi bagian terpenting dalam kurikulum pendidikan nasional dan sudah dilaksanakan. Namun, hasilnya ternyata belum seperti yang diinginkan. Artinya, tidak semua peserta didik menunjukkan kreativitasnya secara baik sehingga peran pendidik di PAUD belum efektif dalam membentuk kreativitas peserta didik. Dalam kenyataannya, pendidik PAUD di Inonesia belum memperoleh haknya untuk dapat mengajar secara profesional dan efektif (Asmani, 2015). Salah satu kemungkinan penyebab rendahnya kreativitas anak Indonesia disebabkan lingkungan yang kurang menunjang anak untuk dapat mengekspresikan kreativitas mereka, khususnya lingkungan keluarga dan lingkungan sekolah. Saat ini orientasi sistem pendidikan di Indonesia lebih mengarah pada pendidikan akademik, mengarah pada upaya membentuk manusia untuk menjadi pintar di sekolah saja bukan untuk menjadi manusia Indonesia seutuhnya (Supriadi dalam Rachmawati, 2012). Selain masalah peran pendidik di PAUD yang belum efektif dalam mengembangkan kreativitas peserta didik, peran orang tua menjadi titik sentral dalam mengembangkan kreativitas anak. Hal tersebut tentu harus diimbangi dengan perhatian orang tua.

Tidak semua yang dikerjakan anak itu dapat dikatakan kreatif. Beberapa perilakunya menirukan apa yang mereka amati pada diri orang lain. Kreativitas bersifat sangat pribadi, 
dimana setiap individu berhak mengekspresikan diri sendiri. Orang kreatif biasanya memiliki kepribadian positif juga kepribadian negatif. Disinilah pentingnya kehadiran seorang pendidik sebagai pembimbing yang akan membantu anak untuk dapat menyeimbangkan perkembangan kepribadiannya, sehingga anak kreatif dapat berkembang secara optimal.

Terlihat bahwa peran pendidik sangat diperlukan dalam mengembangkan kreativitas anak. Hal ini harus mendapatkan perhatian dan kesadaran lebih dari berbagai kalangan terutama pendidik PAUD, orang tua, dan lingkungan. Salah satu institusi pendidikan yang menerapkan pengembangan kreativitas seni anak adalah Pendidikan Anak Usia Dini. PAUD dengan berbasis sentra adalah salah satu wadah yang baik dalam pengembangan kreativitas anak. Hal ini diharapkan dapat membantu mengembangkan kreativitas anak usia dini dengan baik.

\section{METODOLOGI}

Berdasarkan pada pokok permasalahan penelitian yang dikaji, yaitu Peran Pendidik dalam Mengembangkan Kreativitas Seni Anak Usia Dini di Kelopok Bermain Koronka Bawen, maka penelitian ini menggunakan pendekatan deskriptif kualitatif. Penelitian ini dilaksanakan di PAUD Koronka yang bertempat di Jalan Diamond 442-443, Ambarawa Asri, Bawen. Subjek penelitian ini adalah 5 Pendidik Kelompok Bermain Koronka, Pengelola Sekolah, dan Orang Tua Peserta Didik. Fokus dalam penelitian ini adalah Peran Pendidik dalam Mengembangkan Kreativitas Seni Anak Usia Dini di Kelompok Bermain Koroka Bawen. Pengumpulan data dilakukan dengan cara observasi, wawancara, dan dokumentasi. Keabsahan data dengan menggunakan triangulasi sumber dan triangulasi teknik atau metode. Teknik analisis data yang digunakan dimulai dari pengumpulan data, reduksi data, penyajian data \& penarikan kesimpulan atau verifikasi.

\section{HASIL PENELITIAN DAN PEMBAHASAN}

Seni merupakan program ungglan di PAUD Koronka. Terdapat beberapa seni yang diajarkan sebagai penunjang program ekstrakulikuler, seperti drum band, perkusi, keyboard, angklung, dan rebana. Program ekstrakulikuler tersebut dilaksanakan setiap seminggu sekali. Pembelajaran di Kelompok Bermain Koronka menggunakan metode sentra, yang terdiri atas 4 sentra, yaitu: (a) sentra persiapan; (b) sentra peran; (c) sentra balok; dan (d) sentra alam.

Dengan pembelajaran sentra anak bereksplorasi sesuai dengan keinginannya, dan melatih anak untuk bersifat kreatif. Peran pengelola sangat luar biasa dalam hal kreativitas seni. Beliau bersama istrinya menciptakan gerak dan lagu sebagai penunjang pembelajaran di Kelompok Bermain Koronka. Semua pendidik ditutut untuk menguasai serta dapat memperagakan gerak dan lagu tersebut di depan anak-anak pada awal pembelajaran.

Pendidik yang kreatif akan memberikan efek kreatif juga terhadap peserta didiknya. Rasa ingin tahu anak yang begitu besar merupakan modal mereka untuk melatih berpikir kreatif. Hal ini sesuai dengan pendapat Masnipal (2013) bahwa tidak sulit untuk merangsang tumbuhnya kreativitas anak usia dini, karena karakteristik mereka memang menyukai sesuatu yang baru, asyik, dan menarik. Rasa ingin tahu anak terhadap sesuatu yang baru dan menarik dapat menjadi modal bagi pendidik untuk menciptakan pembelajaran kreatif. Pendidik yang 
kreatif akan menciptakan anak didik yang kreatif. Jadi munculnya kreativitas anak sangat tergantung dari usaha pendidik membuat anak itu kreatif, bukan karena faktor keturunannya. Karena pada dasarnya semua anak kreatif, tergantung usaha yang dilakukan orang dewasa sekitar anak dalam menciptakan lingkungan yang membuat anak tumbuh dengan kreativitas.

Pendidik di Kelompok Bermain Koronka mempunyai jiwa kreatif yang tinggi, mereka membuat sumber belajar sendiri tanpa adanya panduan dengan pemanfaatan lingkungan sekitar (alam dan barang bekas) dan disesuaikan dengan perkembangan sumber belajar yang banyak dipakai di berbagai Sekolah. Kesenian akan diajarkan kepada anak-anak ketika akan dilaksanakan pentas seni. Semua peserta didik dan bahkan orang tua dilibatkan dalam pentas seni tersebut. Semua peserta didik akan menampilkan seni musik (bernyanyi), dan seni tari (menari) sesuai dengan pembagian sebelumnya. Mereka akan dilatih selama dua minggu sebelum pentas seni dilaksanakan.

Peran pendidik PAUD tidak hanya bersifat mengajar, tetapi juga mendidik, membimbing, mengarahkan, melatih, menilai dan mengevaluasi. Hal ini sesuai dengan pendapat Mudlofir (2012) bahwa pendidik adalah guru professional dengan tugas utama mendidik, mengajar, membimbing, mengarahkan, melatih, menilai, dan mengevaluasi peserta didik pada jalur pendidikan formal. Pendidik di Kelompok Bermain Koronka mendidik peserta didiknya dalam hal kreativitas seni dengan cara memberikan tantangan kepada peserta didiknya, memberikan pujian kepada peserta didiknya, dan dibutuhkan pendidik yang mempunyai jiwa kreatif. Untuk menumbuhkan kreativitas anak, mereka perlu dihadapkan pada berbagai kegiatan baru yang bervariasi. Pendidik yang mempunyai jiwa kreatif yang tinggi akan sangat memahami peserta didiknya, sehingga beliau terus mengembangkan dirinya dan berinteraksi dengan hal baru. Orang tua dan pendidik harus mendorong kemandirian anak dalam melakukan sesuatu, menghargai usaha-usaha yang telah dilakukan anak, dan memberikan pujian untuk hasil yang telah dicapainya walau sekecil apapun. Orang tua dan pendidik harus merangsang anak untuk tertarik mengamati dan mempertanyakan tentang berbagai benda atu kejadian di sekelilignya, yang mereka dengar, lihat, rasakan, atau mereka pikirkan dalam kehidupan sehari-hari

Pendidik mengajar peserta didik mengenai kreativitas seni melalui pembelajaran sentra. Di Kelompok Bermain Koronka terdapat 4 sentra, yang terdiri dari sentra persiapan, sentra peran, sentra balok, dan sentra alam. Dengan pembelajaran sentra, anak dilatih untuk berkreatif. Mereka akan bermain sesuai dengan keinginannya ketika berada di sentra. Contohnya, ketika mereka sedang pembelajaran di sentra balok, maka peserta didiknya dibebaskan untuk membuat bentuk sesuai dengan balok-balok yang tersedia. Dan terkadang pendidik memberikan tantangan dengan menyuruh anak untuk membuat rumah-rumahan dari balok tersebut.

Pendidik melatih peserta didiknya dalam hal kreativitas seni melalui program ekstrakulikuler. Pedidik terlebih dahulu latihan dengan Pengelola Sekolah sampai benar-benar hafal sebelum mereka melatih peserta didiknya. Pengelola Sekolah PAUD Koronka memiliki jiwa kreativitas yang tinggi. Pak Heru ahli di bidang musik, sedangkan Bu Tini ahli di bidang tari. Mereka memadukan gerak dan lagu sebagai penunjang pembelajaran. Program ekstrakulikuler yang ada di PAUD Koronka adalah seputar program seni musik dan seni tari. 
Peserta didik akan dilatih terus secara 3 minggu berturut-turut sebelum pelaksanaan pentas seni. Pentas seni tersebut dilaksanakan setiap akhir tahun.

Pendidik membimbing peserta didik dalam hal kreativitas seni melalui pendampingan pada saat peserta didik bermain di sentra, dan dengan menyediakan lingkungan yang dapat menstimulasi kreativitas anak. Lingkungan sangat berpengaruh terhadap kreativitas anak. Kreativitas akan muncul ketika anak dihadapkan pada lingkungan yang memadai. Pendidik menilai peserta didik dalam hal kreativitas seni pada saat pelaksanaan pentas seni. Pada saat pentas seni, akan terlihat mana peserta didik yang antusias dan mana peserta didik yang kurang antusias dalam mengikuti kegiatan tersebut. Semua peserta didik akan dilibatkan dalam pentas seni.

Pendidik mengarahkan peserta didik mengenai kreativitas seni dengan memberikan pujian kepada anak, agar anak mempunyai semangat belajar yang tinggi. Pendidik harus sabar dalam menghadapi anak, dan harus memahami setiap peserta didiknya. Pendidik tidak diperbolehkan untuk memarahi peserta didiknya, karena itu dapat mematahkan semangat belajar dan rasa ingin tahu anak yang begitu besar. Ketika anak diberi pengertian secara perlahan maka lama kelamaan mereka akan mengerti.

Pendidik mengevaluasi peserta didik mengenai kreativitas seni dapat dilihat pada saat pentas seni. Bagaimana perkembangan anak ketika latihan dan ketika pelaksanaan pentas seni. Biasanya ada anak yang mempunyai semangat yang tinggi ketika latihan dan pada saat pentas seni berlangsung anak itu tidak mau maju untuk menampilkan apa yang sudah dilatih oleh pendidiknya. Hal ini sesuai dengan pendapat Munandar (dalam Susanto, 2001) bahwa ciri-ciri kreatif yaitu : (a) mempunyai daya imajinasi kuat; (b) mempunyai inisiatif; (c) mempunyai minat luas; (d) mempunyai kebebasan dalam berpikir; (e) bersifat ingin tahu; (f) selalu ingin mendapat pengalaman-pengalaman baru; (g) mempunyai kepercayaan diri yang kuat; (h) penuh semangat; (i) berani mengambil resiko; (j) berani berpendapat dan memiliki keyakinan.

Pendidik dalam mengembangkan kreativitas seni anak usia dini memiliki beberapa faktor pendukung. Untuk menghasilkan anak yang kreatif tentu membutuhkan pendidik yang mempunyai jiwa kreatif. Karena faktor penentu tumbuh kembangnya kreativitas anak terletak kepada pendidik, lingkungan yang mendukung kreativitas, dan dukungan orang tua. Butuh waktu yang lama untuk melatih anak berpikir kreatif, oleh karena itu perlu dilatih dan dididik sejak anak usia dini. Hal ini sesuai dengan pendapat Hurlock dalam Susanto (2011) bahwa faktor pendorong kreativitas adalah: (a) waktu; (b) kesempatan menyendiri; (c) dorongan terlepas dari seberapa jauh prestasi anak memenuhi standar orang dewasa; (d) sarana; (e) lingkungan yang merangsang; (f) cara mendidik anak; dan (g) kesempatan untuk memperoleh pengetahuan.

Sedangkan faktor penghambat kreativitas seni anak usia dini dipengaruhi oleh pendidik atau orang tua yang mematahkan ide yang dikemukakan anak, persaingan antar anak, pembatasan terhadap rasa ingin tahu anak, pendidik yang banyak melarang anak, serta pola asuh orang tua yang terlalu mengawasi anak. Pola asuh orang tua sangat berpengaruh terhadap kepribadian anak. Banyak orang tua yang mendukung kreativitas anak, tetapi ada juga orang tua yang tidak mendukung kreativitas anaknya. Orang tua yang ketat mengawasi kegiatan anak 
akan berpengaruh terhadap kreativitas anak. Anak usia dini merupakan usia dimana mereka mempunyai rasa ingin tahu yang begitu besar. Mereka bereksplorasi dari apa yang mereka lihat, dan apa yang mereka dengar. Anak akan terkekang jika diawasi terlalu ketat oleh orang tuanya. Hal ini sesuai dengan pendapat Munandar dalam Susanto (2011) bahwa sifat orang tua yang menghambat pengembangan kreativitas seni adalah: (a) mengatakan kepada anak bahwa ia akan dihukum jika berbuat salah; (b) tidak membolehkan anak menjadi marah terhadap orang tua; (c) tidak membolehkan anak mempertanyakan keputusan orang tua; (d) tidak membolehkan anak bermain dengan yang berbeda dari keluarga anak yang mempunyai pandangan dan nilai yang berbeda dari keluarga anak; (e) anak tidak boleh berisik; (f) orang tua ketat mengawasi anak; ( $\mathrm{g}$ ) orang tua memberi saran-saran spesifik tentang penyelesaian tugas; (h) orang tua kritis terhadap anak dan menolak gagasan anak; (i) orang tua tidak sabar terhadap anak; (j) orang tua dan anak ada kekuasaan; (k) orang tua menekan dan memaksa anak untuk menyelesaikan tugas.

\section{KESIMPULAN}

\section{Kesimpulan}

Peran pendidik dalam mengembangkan kreativitas seni meliputi mendidik, mengajar, membimbing, mengarahkan, melatih, menilai, dan mengevaluasi peserta didik. Para pendidik Kelompok Bermain Koronka mendidik peserta didiknya dengan cara memberikan tantangan, dan memberikan pujian. Pembelajaran yang digunakan oleh pendidik Kelompok Bermain Koronka menggunakan pembelajaran sentra. Untuk menumbuhkan jiwa kreativitas anak diperlukan pendidik yang mempunyai jiwa kreatif dengan menyediakan lingkungan yang dapat menstimulasi kreativitas anak. Pendidik selalu mendampingi anak pada saat bermain di sentra, tetapi tidak diperbolehkan untuk terlalu melarang dan mengawasi kegiatan anak. Penilaian kreativitas seni anak dapat dilihat pada saat pelaksanaan pentas seni di acara tutup tahun.

Faktor pendukung dalam mengembangkan kreativitas seni anak usia dini, diantaranya: (a) terpenuhinya sarana dan prasarana yang memadai; (b) pendidik yang kreatif; (c) hubungan kerja sama yang baik dengan anak; dan (d) dukungan orang tua. Faktor penghambat kreativitas seni anak dipengaruhi oleh pendidik atau orang tua yang mematahkan ide yang dikemukakan anak, persaingan antar anak, pembatasan terhadap rasa ingin tahu anak, pendidik yang banyak melarang anak, serta pola asuh orang tua yang terlalu mengawasi kegiatan anak.

\section{Saran}

Berdasarkan hasil penelitian dan simpulan yang telah diuraikan, maka untuk mengatasi hambatan-hambatan disarankan, pendidik lebih memperhatikan kegiatan anak, tetapi tidak harus terlalu mengawasi dan melarang anak. Pendidik hanya disuruh untuk mendampingi ketika anak sedang bermain di sentra. Selain itu pendidik harus lebih memperhatikan lingkungan disekitar anak. Untuk melatih anak mempunyai jiwa kreatif, maka diperlukan lingkungan yang mendukung anak dalam mengembangkan kreativitas. Karena jiwa kreatif anak perlu dipupuk sejak anak 


\section{DAFTAR PUSTAKA}

Asmani, Jamal Ma'mur. 2015. PanduanPraktisManajemenMutu Guru PAUD. Yogyakarta: Diva Press.

Masnipal. 2013. Siap Menjadi Guru dan Pengelola PAUD Profesional (Pijakan Mahasiswa, Guru \& Pengelola TK/RA/KB/TPA). Jakarta: PT Elex Media Kumpotindo.

Mulyasa. 2012. Manajemen PAUD. Bandung: PT RemajaRosdakarya.

Rachmawati dan Kurniati. 2012. Strategi Pengembangan Kreativitas pada Anak Usia Taman Kanak-kanak. Jakarta: Prenada Media Group.

Susanto, Ahmad. 2011. Perkembangan Anak Usia Dini: Pengantar dalam Berbagai Aspeknya. Jakarta: Prenada Media Group. 